\title{
Éditorial
}

\section{Perspectives actuelles pour l'analyse, la simulation et la synthèse de mouvements sportifs}

Tout au long du $20^{\mathrm{e}}$ siècle, les inventions technologiques ont largement contribué à modifier nos modes de vie. Actuellement, le développement rapide des technologies numériques a changé notre rapport au monde qui nous entoure en un laps de temps extrêmement court. Ces (r)évolutions ont bien entendu de fortes répercussions sur notre façon de conduire les activités de recherche dans le domaine de la motricité humaine.

La démarche scientifique que nous suivons dans ce domaine spécifique ainsi que les outils que nous utilisons font suite aux travaux novateurs menés par Étienne-Jules Marey et Georges Demenÿ à l'institut de physiologie situé au parc des princes, Paris. Il y a 130 ans, ces précurseurs ont posé les bases de l'analyse cinématographique et dynamographique du mouvement et conçu les instruments de mesure spécifiques (chronophotographe, fusil photographique, dynamographe, etc.) dévolus à l'analyse du mouvement. Ces instruments sont en perpétuelle évolution afin d'améliorer leur précision de mesure, de diminuer encombrement et coût, de faciliter leur utilisation, etc. Pour autant, les principes de base restent identiques à ceux préconisés par Marey et ses collaborateurs.

Au cours de ces vingt dernières années, les importantes évolutions technologiques ont eu pour conséquence une utilisation de plus en plus fréquente de ces instrumentations tant dans le domaine de l'analyse du mouvement humain (en vue d'applications cliniques, sportives, ergonomiques, etc.) que dans les domaines de l'animation ou de la réalité virtuelle. Il n'en demeure pas moins que l'expérimentateur se doit de maîtriser l'ensemble de la chaîne de mesure utilisée (les inévitables incertitudes de mesures) afin de fournir la meilleure estimation (leur propagation dans les quantités calculées) du mouvement étudié. Cette démarche passe obligatoirement par une solide formation en métrologie et la mise à niveau des connaissances du matériel utilisé en fonction de ces évolutions tout au long de la vie professionnelle des expérimentateurs.

Un autre héritage des travaux de Marey et collaborateurs est la représentation du corps humain en mouvement sous la forme d'un système multicorps. Actuellement, les bases théoriques ainsi que les modes calculatoires pour ce type de modélisation sont principalement développés en robotique. Il est bien évident que des particularités propres au corps humain (contraintes anatomiques, géométrie des masses, etc.) doivent être prises en compte. Quoi qu'il en soit, les fondements théoriques de la démarche restent identiques. Ils permettent d'analyser les mouvements du système multicorps au cours du temps (modèle descriptif), de simuler ces mouvements (modèle prédictif), sans oublier les lois de commande qui coordonnent ce système multicorps.

Il advient alors que l'analyse tridimensionnelle du mouvement humain ou animal requière des compétences issues de multiples disciplines. Le spectre de ces compétences est large et, de façon non exhaustive, comprend les sciences pour l'ingénieur et le génie médical. Cette approche multi-/ trans-disciplinaire est extrêmement difficile à mettre en œuvre et à animer. Elle est cependant fondamentale pour apporter des répondes pertinentes aux questionnements de nos contemporains.

Le symposium «Sport, mesure \& simulation », organisé à Poitiers en juin 2011, avait pour ambition de contribuer à cet objectif. Il était organisé sous l'égide conjointe de l'Association des chercheurs en activités physiques et sportives (Acaps) et de la Société de biomécanique (Sb), deux sociétés savantes reconnues internationalement dans les thèmes scientifiques structurant ce symposium.

Ce symposium comprenait également deux ateliers scientifiques portant respectivement sur l'acquisition, le traitement et l'interprétation de signaux électromyographiques et dynamométriques. Ces deux ateliers ont été animés par les sociétés Delsys et Sensix. Ils répondaient à un besoin de formation ou d'approfondissement des connaissances dans ces domaines exprimé de longue date par des collègues et des doctorants. Une des originalités de ces ateliers est qu'ils reposaient sur l'acquisition de signaux réalisée en présence de l'audience.

De plus, ce symposium a été choisi par l'Académie nationale olympique française (Anof) pour délivrer le prix Jean Vivès 2011. Ce prix récompense les travaux d'un chercheur francophone dans le domaine des sciences pour 
l'ingénieur appliqué au sport. Le jury, composé de personnalités internationales, a remis ce prix à Antoine Nordez de l'université de Nantes.

L'organisation du symposium «Sport, mesure \& simulation » n'a été possible que part le fort soutient de partenaires académiques (Faculté des sciences du sport, université de Poitiers), institutionnels (Acaps, Anof, Cper 2007-2013 《savoir, images, société » (État/Région Poitou-Charentes/Union européenne), Communauté d'agglomération grand Poitiers, Conseil général de la Vienne, Région Poitou-Charentes, Science \& motricité, $\mathrm{SB}$ ) et industriels (Biometrics France, DelSys, EDP sciences, Kistler France, Sensix Force-Torque Sensors) qui ont tenu à s'associer à cette manifestation scientifique. Je les en remercie vivement.

Ce numéro spécial comprend onze contributions sélectionnées par le Comité scientifique constitué à l'occasion de ce symposium. Ce Comité a également expertisé ces contributions ré-écrites sous la forme d'articles scientifiques. Je voudrais remercier l'ensemble des membres de ce Comité qui s'est acquitté avec sérieux et brio de cette tâche très délicate. Ils ont su, par leur remarques et suggestions pertinentes, améliorer la qualité scientifique de ce numéro spécial.

Ce numéro spécial est structuré en trois sections. La première section porte un regard novateur sur notre compréhension de la motricité humaine par l'utilisation de techniques numériques développées dans le champ de la robotique, la fusion de données expérimentales propre à la physiologie humaine dans ces modèles numériques ou les perspectives que dégage un nouveau champ expérimental.

- Katja Mombaur et Thorsten Stein (université d'Heidelberg et université technologique de Karlsruhe, Allemagne, LAAS-CNRS, France) s'interrogent sur la pertinence des méthodes numériques de contrôle optimal pour générer des mouvements humains. Après avoir présenté les bases mathématiques de ces méthodes, les auteurs illustrent leur propos par des exemples provenant de mouvements sportifs de disciplines aussi variées que la gymnastique, la course et le plongeon. Ces méthodes prédictives se différencient de la simulation par le calcul simultané de la cinématique et de la dynamique du système multicorps satisfaisant un critère d'optimisation. Ainsi, le mouvement prédit est en adéquation avec les forces qui génèrent ce mouvement. Il est alors possible d'explorer les mécanismes sous-jacents à la coordination de ces mouvements sur la base d'équations du mouvement respectées. Leurs résultats suggèrent que les méthodes de contrôle optimal pourraient apporter des perspectives dans le domaine de l'apprentissage de tâches complexes.

- Fabien Leboeuf, Pascal Seguin et Patrick Lacouture (centre hospitalier universitaire de Nantes et université de Poitiers, France) questionnent la coordination de la phase aérienne d'un salto arrière par synthèse optimale sous contrainte d'un critère d'optimisation sthénique. Les couples optimaux ainsi obtenus sont comparés à ceux calculés plus classiquement par dynamique inverse. Il ressort de cette étude la complémentarité entre ces deux approches : le mouvement prédit est proche de celui réalisé. Les couples optimaux ne sont pas entachés des incertitudes liées au calcul itératif du modèle descriptif. Des hypothèses peuvent alors être formulées sur le contrôle de ce mouvement.

- David Amarantini, Guillaume Rao, Luc Martin, Violaine Cahouët et Eric Berton (université de Toulouse, université de la méditerranée et université de Grenoble 1, France) s'intéressent aux tensions musculaires mises en jeu au cours du mouvement. Ce problème sous-déterminé, le nombre d'actionneur est supérieur au nombre d'équation, est classiquement abordé par des approches numériques d'optimisation statique. Ils proposent une méthode «EMG-assistée » reposant sur une étape de calibration isométrique et une procédure d'optimisation qui intègre des données électromyographiques en entrée. Ce modèle fournit des résultats (couples actionneurs agoniste et antagoniste, tensions musculaires et indices de co-contraction) physiologiquement réalistes lors de mouvements isométriques ou dynamiques en présence ou non de fatigue.

- Antoine Nordez, Killian Bouillard et François Hug (université de Nantes, France) proposent une méthode expérimentale originale pour quantifier l'état de contraction du muscle. Leur travail s'appuie sur une nouvelle méthode d'élastographie, dénommée «Supersonic Shear Imaging », pour estimer le module d'élasticité de cisaillement du muscle, paramètre corrélé au niveau d'activité électrique de ce muscle. Un des avantages que présente cette méthode est la mesure de muscles profonds, inaccessibles par électromyographie de surface. Leurs résultats, issus de plusieurs expérimentations, tendent vers une estimation de la force musculaire in vivo.

La seconde section est composée de contributions portant sur la simulation de mouvements sportifs.

- Mike Hiley (université de Loughborough, GrandeBretagne) met en évidence l'apport de critères issus du contrôle moteur tels que la coordination et la précision de synchronisation dans la simulation de mouvements gymniques. Ce point de vue est supporté par les résultats issus de trois études portant sur la technique des balancés en gymnastique. L'auteur montre que le poids de ces critère est au moins aussi important que les critères sthénique ou énergétique classiquement implémentés pour appréhender de façon réaliste la performance dans ces situations spécifiques.

- Patrick Cangley, Louis Passfield, Helen Carter et Martin Bailey (université de Brighton et université de Kent, Grande-Bretagne) développent un modèle dynamique 3D de l'activité cyclisme qui comprend la dynamique de la bicyclette, un modèle de pneumatique, la biomécanique du cycliste et des facteurs environnementaux. Les auteurs proposent un développement détaillé de leur modèle au 
cours duquel le lecteur est guidé de façon très didactique. Les simulations sont sont validées par deux approches complémentaires. La stabilité des calculs est évaluée au regard des résultats d'une étude «benchmark » précédemment publiée, d'une part, les simulations sont comparées à des résultats obtenus par des cyclistes élites en condition écologique de pratique, d'autre part.

- John Rasmussen, Joakim Holmberg, Kasper Sørensen, Maxine Kwan, Michael Skipper Andersen et Mark de Zee (université d'Aalborg, Danemark, université de Linköping et université du centre de la Suède, Suède) génèrent des simulations à partir d'un modèle intégrant la géométrie et la dynamique des muscles actionneurs du mouvement. Deux activités sportives fort différentes, le ski de fond et le badminton, montrent la pertinence de cette approche en vue d'optimiser les performances sportives. Elle permet d'accéder à des mécanismes complexes mettant en jeu l'ensemble de la structure musculo-squelettique. Sportifs et entraîneurs reçoivent ainsi des éléments pour répondre à la question du « savoir-pourquoi » plutôt qu'au « savoirfaire $\gg$. Les auteurs suggèrent un apprentissage plus rapide de mouvements complexes.

- Alban Leroyer, Sophie Barré et Jean-Michel Kobus (école centrale de Nantes, France) montrent intérêt et difficulté de mener simultanément des approches expérimentale et numérique afin d'optimiser la performance sportive sur la base de mouvements réalistes. Ils illustrent avec justesse leurs propos par une application extrêmement complexe : la propulsion des bateaux d'aviron. Leurs premières comparaisons simulation/résultat expérimental mettent en défaut les modèles quasi statique au vu de la forte instationnarité de l'écoulement autour des palettes et la proximité de la surface libre violemment perturbée en conséquence. Ils orientent leur approche numérique vers l'utilisation de méthodes plus avancées, tel que le raffinement automatique de maillages pour, à terme, les comparer à des données obtenues en condition écologique de pratique.

La dernière section met l'accent sur l'analyse du mouvement par des modèles descriptifs.
- William Samson, Bruno Dohin, Angèle Van Hamme, Raphaël Dumas et Laurence Chèze (Centre technique du cuir, université de Saint-Étienne et université de Lyon, France) s'intéressent à la marche chez l'enfant de moins de six ans avec et sans chaussage. Ils montrent que la dynamique interne de l'ensemble du membre inférieur est affecté par le port de chaussure et par la vitesse de déplacement. Les auteurs suggèrent que l'âge, mais aussi la vitesse de déplacement, doivent être considérés pour l'étude de la marche chaussée chez l'enfant, et donc pour la conception de chaussure.

- Peter Sinclair, Cherie Walker et Thomas Rickards (université de Sydney, Australie) rapportent une expérimentation dont le but est d'identifier les variables cinématiques déterminantes dans la hauteur du plongeon. Chez de jeunes athlètes, ils mettent en évidence l'importance de la phase préparatoire sur la coordination observée lors de la phase de contact avec la planche et les conditions d'éjection.

- Marc Therrien, Floren Colloud et Mickaël Begon (université de Montréal, Canada et université de Poitiers, France) marient avantageusement approche descriptive (cinématique tridimensionnelle et force de contact générées par l'athlète sur ergomètre) et approche prédictive (modèle d'avancement du système \{bateau-athlètepagaie\}) afin d'estimer la trajectoire probable de la pagaie en condition écologique de pratique. Ils montrent une forte reproductibilité de la gestuelle pour un même athlète quelque soit la cadence observée, mais des différences significatives entre athlètes malgré le haut niveau de performance des sujets. L'augmentation de la cadence implique une diminution du déplacement antéropostérieur de la pale dans la phase de propulsion alors que les phases d'accroche et de dégagé restent inchangées.

Je vous souhaite une bonne lecture de ce numéro spécial. Je suis sûr que vous retrouverez à travers ces articles la grande qualité scientifique et l'esprit convivial qui ont animé ce symposium.

Floren Colloud Éditeur invité 


\section{Éditorial}

\section{Current perspectives for analysis, simulation and synthesis of sports movement}

Throughout the $20^{\text {th }}$ century, technological inventions have contributed to change our lifestyles. Currently, the rapid development of digital technologies has changed our relationship to the world surrounding us in a very short period of time. These (r)evolutions have, of course, a major impact on how we conduct research in the field of human movement sciences.

The scientific approach we follow in this specific area and the devices we use are the result of pioneering work carried out by Étienne-Jules Marey and George Demenÿ at the Institut de Physiologie located in Paris at the Parc des Princes. One hundred and thirty years ago, these precursors have laid the foundation of cinematographic and dynamographic analysis and designed specific experimental devices (chronophotograph, photographic gun, dynamograph, etc.) for motion analysis. These devices are constantly evolving in order to improve accuracy, reduce size and cost, ease of use, etc. However, the basic principles remain the same as those recommended by Marey and collaborators.

During the past two decades, significant technological developments have led to increasingly common usage of these devices in the field of human motion analysis (for clinical, sport or ergonomic applications), as well as in the fields of animation and virtual reality. The fact remains that researchers must control inevitable uncertainties propagating throughout the entire chain of measurement to provide the best estimate of the movement analysed. Researchers require a strong background in metrology and a continuous upgrading of their knowledge on these specific devices throughout their whole working life.

Another legacy of Marey and collaborator's work is the modelling of the human body in movement as a multibody system. Currently, the theoretical and computational methods for this kind of modelling are mainly developed in robotics. It is obvious that the special features of the human body (anatomical constraints, geometry, segments inertia, etc.) must be taken into account. Nevertheless, the theoretical foundations of the approach remains the same; they allow one to analyse the movement of multi-body systems over time (descriptive model), to simulate the movements (predictive model), while descri- bing the control laws that coordinate the multi-body system.

As a result, three-dimensional analysis of human or animal movement requires skills from multiple disciplines. The spectrum of these skills is broad; it includes, but is not limited to, the engineering sciences and medical engineering. This multi-/ trans-disciplinary approach is extremely difficult to implement and conduct. However, this multi-/ trans-disciplinary approach is crucial to provide pertinent answers to our questions.

The "Sports, Measure \& Simulation" Symposium, held in Poitiers in June 2011, had the ambition to contribute towards this goal. It was organised under the joint aegis of the Association des Chercheurs en Activités Physiques et Sportives (ACAPS) and the Société de Biomécanique (SB), two international scientific societies recognised in the scientific themes structuring the Symposium.

This Symposium also included two scientific workshops on the acquisition, processing and interpretation of torque and electromyographic signals, respectively. Both workshops were co-organised with Sensix and Delsys. They were responding to a need for development of knowledge in these areas expressed by colleagues and $\mathrm{PhD}$ students. One of the origins of these workshops is that they were based on signals acquired in the presence of the participants.

The "Sports, Measure \& Simulation" Symposium was chosen by l'Académie Nationale Olympique Française (ANOF) to deliver the Jean Vivès 2011 award. This award rewards the work of a young French-speaking researcher in the field of sport engineering sciences. The jury, composed of international personalities, delivered this award to Antoine Nordez from l'Université de Nantes.

The organisation of the "Sports, Measure \& Simulation" Symposium was strongly supported by academic (Faculté des Sciences du Sport, Université de Poitiers), institutional (ACAPS, ANOF, CPER 2007-2013 «Savoir, Images, Société » (État/Région Poitou-Charentes/Union Européenne), Communauté d'Agglomération Grand Poitiers, Conseil Général de la Vienne, Région PoitouCharentes, Science \& Motricité, SB) and industrial (Biometrics France, Delsys, EDP Sciences, Kistler France, 
Sensix Force-Torque Sensors) partners who joined this scientific event. I would like to acknowledge made by all of them.

This Special Issue includes eleven contributions selected by the Scientific Committee of the "Sports, Measure \& Simulation" Symposium. This Committee also reviewed the contributions re-written as scientific articles. I want to warmly thank all the members of this Committee who have performed this very delicate task with seriousness and panache. They really contributed to improve the scientific quality of this Special Issue by their pertinent comments and suggestions.

This Special Issue comprises three sections. The first section presents innovative approaches to improve our knowledge of human movement coordination using numerical optimisation developed in the field of robotics, the fusion of experimental data specific to human physiology in these numerical models, or a new perspective that emerges from experimentation.

- Katja Mombaur and Thorsten Stein (University of Heidelberg and Karlsruhe Institute of Technology, Germany, LAAS-CNRS, France) highlight the interest of optimal control methods to generate human movement. After presenting the mathematical basis of these methods, the authors illustrate their points with examples from sports movements in disciplines as varied as gymnastics, running and diving. These predictive methods differ from simulation by computing simultaneously the kinematics and dynamics of multi-body systems satisfying an optimisation criterion. Thus, the predicted movement is consistent with the forces that generate movement. It is then possible to explore the mechanisms underlying the coordination of these movements on the basis of equations of motion observed. Their results suggest that optimal control methods could provide opportunities in the field of complex task motor learning.

- Fabien Leboeuf, Pascal Seguin and Patrick Lacouture (Centre Hospitalier Universitaire de Nantes and Université de Poitiers, France) question the coordination performed during the aerial phase of a backward somersault using optimal synthesis constrained by a sthenic optimisation criterion. Optimal joint torques were compared with those resulting from more conventional inverse dynamics. This study shows the complementarity between these two approaches: optimal synthesis produces a somersault closely mimicking the experimental one while optimal joint torques are not biased by the propagation of the uncertainties due to the iterative process of the descriptive model. Thus, assumptions can be made on the control of the movement.

- David Amarantini, Guillaume Rao, Luc Martin, Violaine Cahouët and Eric Berton (Université de Toulouse, Université de la Méditerranée and Université de Grenoble 1 , France) challenge the estimation of muscle tension generated during movement. This under-determined problem, the number of actuator exceeds the number of equations, is conventionally addressed by static optimisation approaches. They propose a two-step "EMG-based" method including an isometric calibration and an optimisation procedure that incorporates electromyographic data input. This model provides results (agonist and antagonist joint torques, muscle tension and co-contraction level) physiologically realistic for isometric or dynamic movements, with or without fatigue.

- Antoine Nordez, Killian Bouillard and François Hug (Université de Nantes, France) offer a unique experimental method to quantify the muscle contraction state. Their work is based on a new elastography method, called "Supersonic Shear Imaging," to estimate the shear modulus of elasticity of muscle, a parameter correlated with the level of electrical activity of the muscle. One of the advantages of this method is the measurement of deep muscles, inaccessible by surface electromyography. Their results from several experiments are promising for the estimation of muscle tension in vivo.

The second section consists of contributions on numerical simulation of sports movement.

- Mike Hiley (Loughborough University, United Kingdom) highlights the contribution of motor control criteria such as the coordination and synchronisation accuracy in the simulation of gymnastic movements. This view is supported by the results of three studies on gymnastics swinging techniques. The author shows that the weight of these criteria is at least as important that sthenic or energy criteria usually implemented to understand performance in these situations in a realistic way.

- Patrick Cangley, Louis Passfield, Helen Carter and Martin Bailey (University of Brighton and University of Kent, United Kingdom) develop a 3D dynamic model of cycling including bicycle dynamics, a tyre model, rider biomechanics and environmental factors. The authors propose a detailed development of their model in which the reader is guided in a very didactic way. The simulations are validated by two complementary approaches. On one hand, stability calculations is assessed using a "benchmark" previously published, on the other hand, the simulations are compared with results obtained in situ by elite cyclists.

- John Rasmussen, Joakim Holmberg, Kasper Sørensen, Maxine Kwan, Michael Skipper Andersen and Mark de Zee (Aalborg University, Denemark, Mid Sweden University and Linköping University, Sweden) generate simulations from a model incorporating the geometry and dynamics of muscles that actuate movements. Two very different sports, cross country skiing and badminton, show the relevance of this approach to optimisation of athletic performance. It provides access to complex mechanisms involving the whole elements of the musculoskeletal model. This approach can provide to athletes and coaches elements to answer the question of "know-why" rather than "know-how." The authors suggest that complex movements could be learnt at a faster rate using this method. 
- Alban Leroyer, Sophie Barré and Jean-Michel Kobus (École Centrale de Nantes, France) show both the interest and difficulty of conducting simultaneous experimental and numerical approaches to optimise athletic performance based on realistic movements. They illustrate their remarks with accuracy using a highly complex application: propulsion in rowing. Their first comparisons of simulation versus experimental results highlight that usual quasistatic models are not appropriate for this application due to the flow around the blades and the proximity of the free surface severely disrupted as a result. The authors orient their numerical approach to the use of more advanced methods, such as the automatic mesh refinement, and compare their results with data obtained in situ.

The final section focuses on the analysis of movement using descriptive models.

- William Samson, Bruno Dohin, Angèle Van Hamme, Raphaël Dumas and Laurence Chèze (Centre Technique du Cuir, Université de Saint-Étienne and Université de Lyon, France) analyse the effect of wearing shoes during gait performed by children under 6 years old. They show that the nett joint torques of the lower limb are affected by wearing shoes and by the gait velocity. The authors suggest that age, but also gait velocity, should be considered for the study of children gait with shoes and therefore for the design of shoe.
Peter Sinclair, Cherie Walker and Thomas Rickards (The University of Sydney, Australia) analyse the key kinematic variables to obtain the highest height during diving. For young athletes, they highlight the importance of the preparatory phase on coordination observed in both the contact phase with the board and the ejection parameters.

- Marc Therrien, Floren Colloud and Mickaël Begon(Université de Montréal, Canada and Université de Poitiers, France) mixed advantageously both descriptive (three-dimensional kinematics and contact force generated by athlete on ergometer) and predictive approaches (displacement model of the system \{boat-athlete-paddle\}) to estimate the paddle trajectory in situ. They show high intra-athlete reproducibility of the trajectories whatever the rate paddled, but significant inter-athlete differences between athletes despite all of them being elite athletes. Increasing the paddling rate implies a decrease in the antero-posterior displacement of the blade during the propulsion, while catch and released phases remain constant.

I hope you enjoy reading this Special Issue. I'm sure you will find within these articles both the high scientific quality and the friendly spirit that animated the Symposium.

Floren Colloud Guest Editor 